\title{
Cytotaxonomical Studies of South Indian Urticaceae
}

\author{
D. Subramanian and A. Thilagavathy \\ Department of Botany, Annamalai University, \\ Annamalainagar-608002, Tamilnadu, India
}

Accepted October 8, 1987

The Urticaceae consist of about 42 genera and nearly 600 species (Lawrence 1957). In South India, there are 15 genera and 33 species, most of which occur in hill stations like Ooty, Kodaikanal and Anamalais of Western Ghats (Gamble 1956). A perusal of the chromosomal data for the family Urticaceae reveals that a total of only 105 species belonging to 21 genera have so far been cytologically investigated from various parts of the world (Fedorov 1974 and Taxon upto 1980). Comparatively little work has been done on the cytology of South Indian species of Urticaceae. The present investigation has been undertaken in order to fill up this gap and in 17 species of this family, detailed cytotaxonomical studies have been undertaken.

\section{Materials and methods}

The species for the present study were collected from Ooty, Kodaikanal, Yercaud and Pulney hills and a few of them were obtained locally. A few of the ornamental species namely Pilea microphylla, $P$. cadierei and Pellionia repens were obtained from Beena nursery, Trichy of Tamilnadu. All these species were grown in our Botanic Garden, under identical conditions in $3 / 4^{\prime}$ clay pots under shade.

The root tips were collected and thoroughly washed in water. Then, they were pretreated in $0.02 \%$ hydroxyquinoline at $4^{\circ} \mathrm{C}$ for 3 hours. Then, the root tips were thoroughly washed

Table 1.

\begin{tabular}{|c|c|c|c|c|}
\hline S. no. & Species studied & $\begin{array}{l}\text { Haploid } \\
\text { number }\end{array}$ & $\begin{array}{l}\text { Diploid } \\
\text { number }\end{array}$ & $\begin{array}{l}\text { Previous reports, } \\
\text { authors and years }\end{array}$ \\
\hline 1 & Laportea teminalis Wight & $\mathrm{n}=10$ & $2 n=20^{*}$ & 一 \\
\hline 2 & Elatostemma sessilis Forst & - & $2 n=32$ & $\begin{array}{l}2 n=32, \text { Strasburger, } \\
1910 ; 2 n=52 \text { Krause, } \\
1931 \text { Lecoq } 1963 .\end{array}$ \\
\hline 3 & E. lineolatum Wight & - & $2 \mathrm{n}=24^{*}$ & - \\
\hline 4 & E. acuminatum Brongn. & - & $2 n=20$ & $2 n=32$, Strasburger, 1910 \\
\hline 5 & E. surculosum Wight & - & $2 n=32^{*}$ & - \\
\hline 6 & Pilea trinervia Wight & - & $2 n=24^{*}$ & - \\
\hline 7 & P. microphylla Lielam & $\mathrm{n}=25^{*}$ & $2 n=50^{*}$ & - \\
\hline 8 & P. cadierei Gagnop & - & $2 n=48$ & $2 n=48$, Hamel 1939 \\
\hline 9 & P. involucrata Hort & $\mathrm{n}=15^{*}$ & $2 \mathrm{n}=30^{*}$ & - \\
\hline 10 & Pellionia repens Hort & $\mathrm{n}=13^{*}$ & $2 n=26^{*}$ & - \\
\hline 11 & Pouzolzia auriculata Wt. & - & $2 n=22^{*}$ & - \\
\hline 12 & P. cymosa Wight & $\mathrm{n}=10^{*}$ & $2 n=20^{*}$ & - \\
\hline 13 & P. wightii Burn & $\mathrm{n}=11^{*}$ & $2 n=22^{*}$ & - \\
\hline 14 & $P$. bennettiana Wight & $\mathrm{n}=12^{*}$ & $2 n=24^{*}$ & - \\
\hline 15 & P. zeylanica Linn & $\mathrm{n}=12^{*}$ & $2 n=24^{*}$ & - \\
\hline 16 & Droguetia diffusa Bedd & - & $2 n=18^{*}$ & - \\
\hline 17 & Villebrunia integrifolia Gaud. & - & $2 n=24^{*}$ & - \\
\hline
\end{tabular}

* First record of $\mathrm{n}$ and $2 \mathrm{n}$ chromosome numbers. 
and fixed in 1: 3 acetic ethanol for 3 hours or overnight and following iron alum haematoxylin squash schedule described by Marimuthu and Subramaniam (1960), squashes were made with 1 or 2 root tips per slide and sealed. Important plates were photographed and camera lucida diagrams were drawn with Abbe camera lucida under oil immersion lens at a magnification of $\times 1250$. 9 plates were considered for karyotype analysis in each species in the present investigation.

The measurements of chromosomes were made with ocular micrometer, the scale of which had been calibrated from stage micrometer. Idiograms were prepared to show the details of

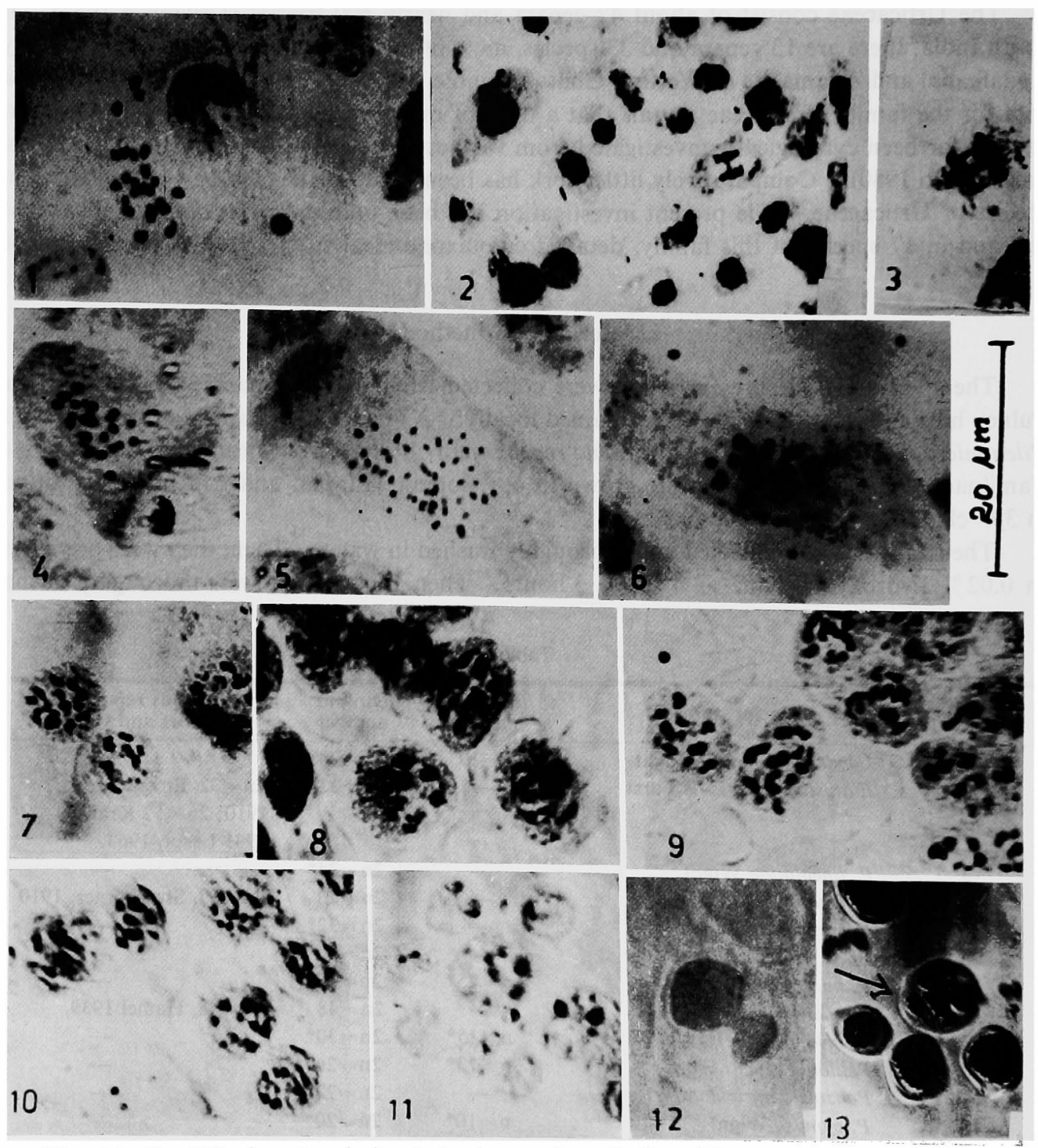

Figs. 1 to 13 . Mitosis and meiosis, photomicrographs. 1, Pouzolzia cymosa, $2 \mathrm{n}=20$ chromosomes. 2, P. cymosa, anaphasic bridge. 3, Pilea trinervia, anaphasic bridge. 4, Pouzolzia wightii $2 \mathrm{n}=24$ chromosomes. 5, P. wightii, polypolid cell. 6 , Villebruunea integrifolia, $2 \mathrm{n}=24$, chromosomes. 7, Pellionia repens, metaphase, polar view. 8, Pouzolzia bennettiana, metaphase, polar view. 9, P. zeylanica, prometaphase. 10, P. wightii metaphase, polar view. 11, Laportia metaphase I, polar view. 12, Pouzolzia cymosa, cytomixis. 13, P. cymosa, polyad. 
karyotypes of various species studied at a glance and from the absolute chromosome length of the species, histogram was prepared.

\section{Observations}

The particulars about the species studied, $2 \mathrm{n}$ chromosome number, the previous chromosome reports, authors and years are furnished in Table 1. The chromosomes of the members of the family Urticaceae are generally short (Figs. 1 to 13). Based on the length, the chromosomes are grouped into the shortest, shorter, short, medium and long types. Under each of

14 ifHinH

iriulIIIIII.

15

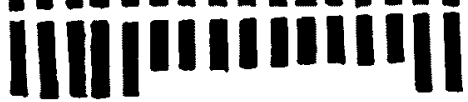

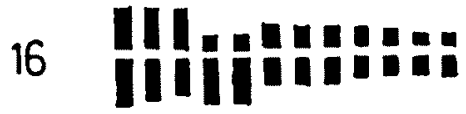

17

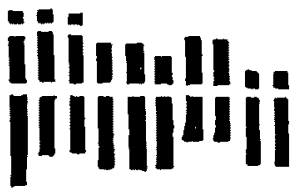

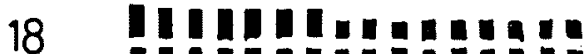

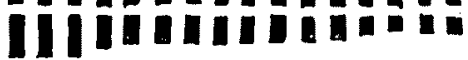

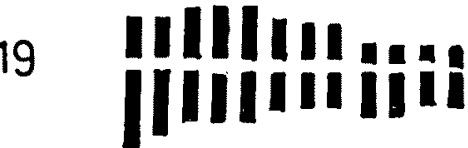

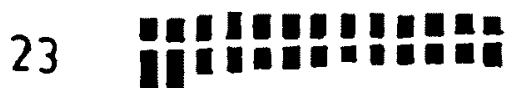

24 Midigngan

25 Intareger

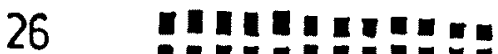

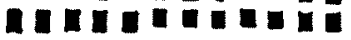

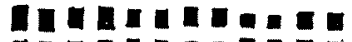
100010010

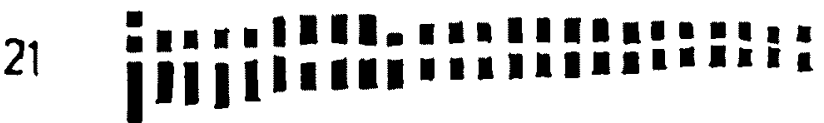

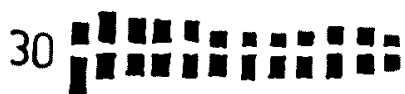

Figs. 14 to 30. Idiograms of various species studied. 14, Laportea terminalis. 15, Elastostemma sessile. 16, E. lineolatum. 17, E. acuminatum. 18, E. surculosum. 19, Pilea trinervia. $20, P$. microphylla. 21, $P$. cadierei. 22, $P$. involucrata. 23, Pellionia repens. 24, Pouzolzia auriculata. 25, P. cymosa. 26, P. wightii. 27, P. bennettiana, 28, P. zeylanica. 29, Droguetia diffusa. 30 , Villebrunea integrifolia. 
these groups the following catagories of chromosomes have been recognized.

Long (Above 2.5 to $3.0 \mu \mathrm{m}$ )

Type A: Chromosome with submedian primary centromere and subterminal secondary

Table 2 .

\begin{tabular}{lccrrrrrl}
\hline \multicolumn{1}{c}{ Taxa } & 1 & \multicolumn{1}{c}{2} & 3 & 4 & 5 & 6 & \multicolumn{1}{c}{7} & \multicolumn{1}{c}{8} \\
\hline Laportea terminalis & 20 & 0.8 to 1.6 & - & 6 & 10 & 4 & 9.8 & 0.98 \\
Elatostemma sessilis & 32 & 1.8 to 2.4 & 2 & 8 & 18 & 4 & 32.0 & 2.0 \\
E. lineolatum & 24 & 0.8 to 1.6 & - & - & 16 & 8 & 13.2 & 1.1 \\
E. acuminatum & 20 & 1.6 to 3.0 & 6 & 6 & 4 & 4 & 21.2 & 2.12 \\
E. surculosum & 32 & 0.8 to 1.4 & - & 16 & 16 & - & 17.2 & 1.075 \\
Pilea trinervia & 24 & 1.0 to 2.2 & - & 4 & 14 & 6 & 19.0 & 1.58 \\
$P$. microphylla & 50 & 0.8 to 1.6 & - & 16 & 24 & 10 & 28.2 & 0.725 \\
$P$. cadierei & 48 & 0.8 to 1.8 & 2 & 8 & 32 & 6 & 25.6 & 1.06 \\
$P$. involucrata & 30 & 0.8 to 2.2 & 2 & 6 & 22 & - & 17.6 & 1.17 \\
Pellionia repens & 26 & 0.8 to 1.2 & - & 6 & 16 & 4 & 12.4 & 0.930 \\
Pouzolzia auriculata & 22 & 0.9 to 2.4 & 2 & 4 & 12 & 4 & 15.2 & 1.38 \\
$P$. cymosa & 20 & 0.8 to 1.4 & - & - & 12 & 8 & 9.6 & 0.96 \\
$P$. wightii & 22 & 9.7 to 1.9 & - & - & 29 & 2 & 8.7 & 0.89 \\
$P$. bennettiana & 24 & 0.8 to 1.2 & - & 4 & 16 & 4 & 12.0 & 1.0 \\
$P$. zeylanica & 24 & 0.6 to 1.0 & - & 12 & 12 & - & 9.6 & 0.8 \\
Droguetia diffusa & 18 & 0.8 to 2.2 & 4 & 4 & 6 & 4 & 13.2 & 1.46 \\
Villebrunea integrifolia & 24 & 0.6 to 1.2 & - & 10 & 14 & - & 10.8 & 0.9 \\
\hline
\end{tabular}

The descriptions of the various columns of Table 2 are as follows: 1 , Chromosome number (2n). 2, Size range in millimicrons. 3, Number of chromosomes with secondary constictions. 4, Number of chromosomes with submedian centromere. 5 , Number of chromosomes with median centromere. 6, Number of chromosomes with subterminal centromere. 7, Absolute chromosome length (Fig. 31) in $\mu \mathrm{m}$. 8, Average chromosome length in $\mu \mathrm{m}$.

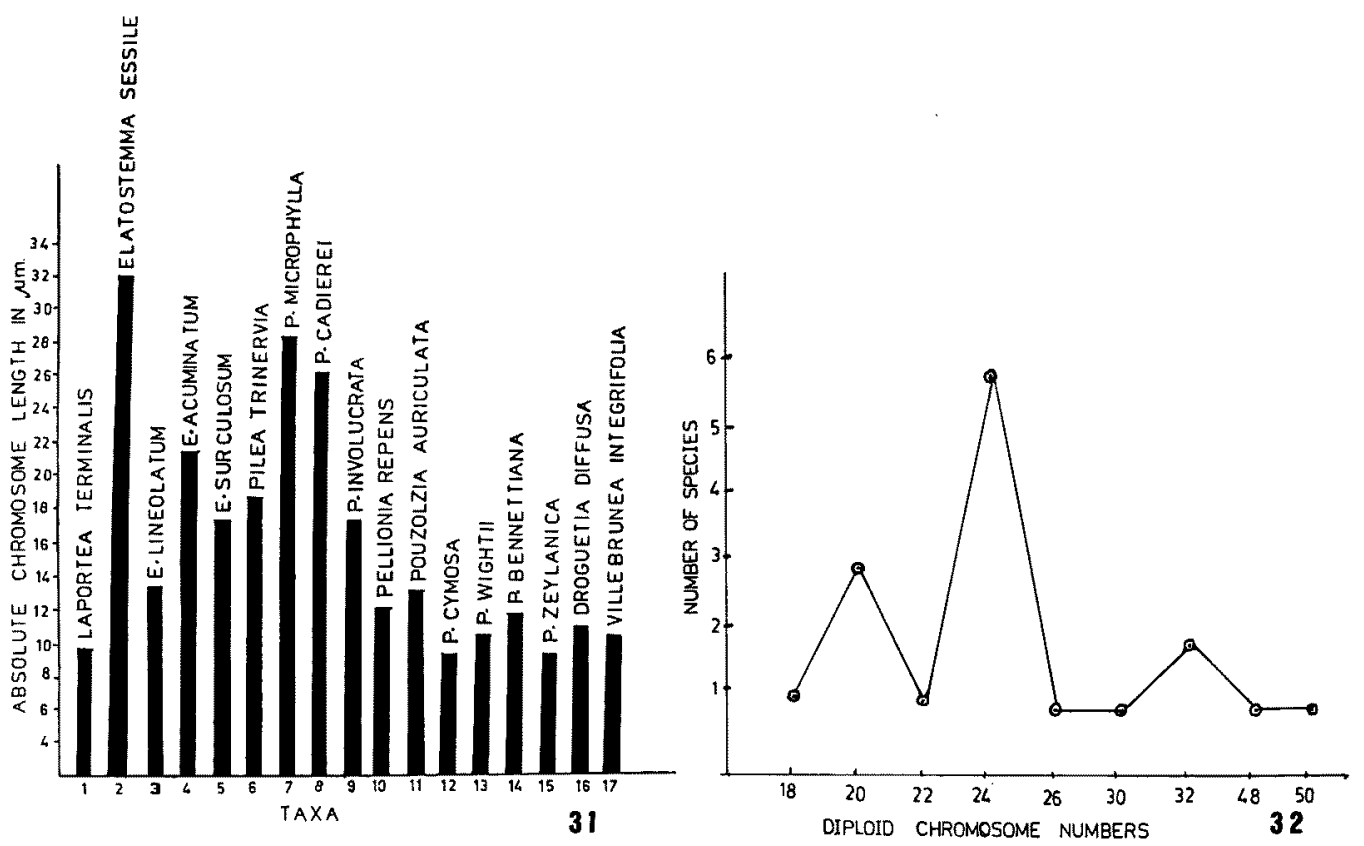

Fig. 31. Histographic representation showing absolute chromosome lengths of species studied.

Fig. 32. Graph showing the frequency distribution of somatic chromosome numbers of the species studied. 


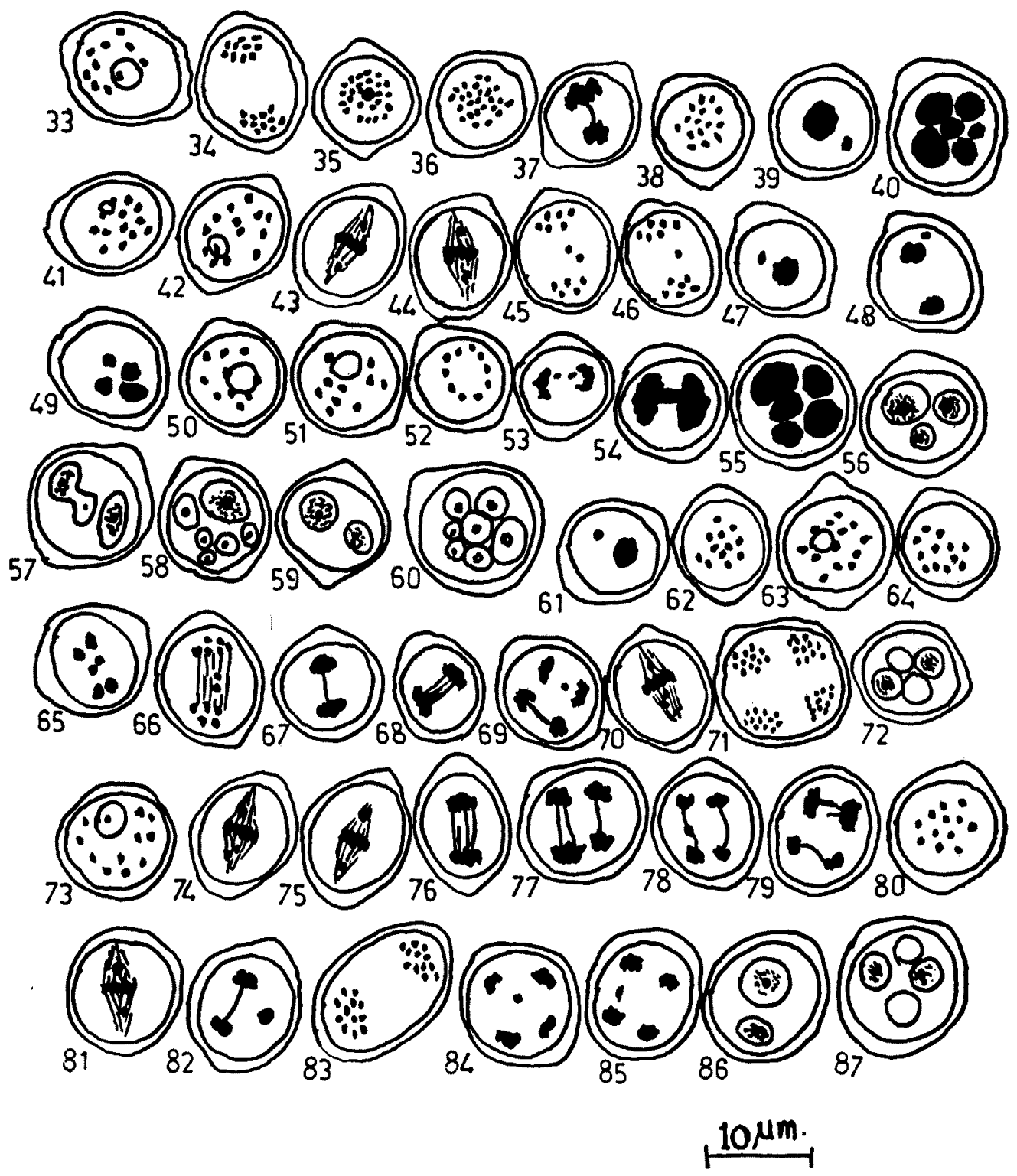

Figs. 33 to 87. Meiosis; drawings. 33 and 34, Laportea terminalis, prometaphase and metaphase and metaphase II with 10 bivalents in each. 35 to 37 , Pilea microphylla. 35 and 36 , prometaphases with 25 bivalents. 37, anaphasic bridge. 38 to 40 , Pilea involucrata. 38, prometaphase with 15 bivalents. 39, precocious movements. 40, polyad. 41 to 49 : Pellionia repens. 41 and 42, prometaphase with 13 bivalents. 43 and 44, precocious movements of chromosomes. 45 and 46, laggards. $47, \mathrm{~B}$ chromosomes at metaphase $48=\mathrm{B}$ chromosome at late anaphase II. 49, multivalents. 50 to 61 : Pouzolazia cymosa. 50 to 51 , metaphase with 10 bivalents. 52 , chromosomal rings. 53, laggards. 54,55 and 57, cytomixis. 56, triad. 59 , tetrad with 2 pollens. 58 and 60 , polyads. 61, B chromosomes. 62 to 72 : P. wightii. 62 to 64 , prometaphase with 12 bivalents. 65 , quadrivalants. 66 , laggards. 67 to 69, anaphasic bridges. 70, precocious movement. 71 , anaphase II with 12 chromosomes at each pole. 72 , isobilateral tetrad with 2 sterile pollens. 73 to $79: P$. bennettiana. 73 , metaphase with 12 bivalents. 74 and 75 , precocious movements. 76 to 79 , anaphasic bridges. Figs. 80 to $87, P$. zeylanica. 85 , metaphase with 12 bivalents. 81 , precocious movements. 82 , anaphasic bridge. 83 , metaphase II. 85 and 86 , laggards. 87, PMC with 2 pollens. 87 , tetrad with 2 sterile pollens. 
centromere.

Medium (Above $20 \mu \mathrm{m}$ to $2.5 \mu \mathrm{m}$.)

Type B: Chromosome with submedian primary centromere and subterminal secondary centromere

Type C: Chromosome with submedian centromere.

Short (Above $1.5 \mu \mathrm{m}$ to $2.0 \mu \mathrm{m}$ )

Type D: Chromosome with submedian primary centromere and subterminal secondary centromere.

Type E: Chromosome with submedian centromere.

Type F: Chromosome with median centromere.

Type G: Chromosome with subterminal centromere.

Shorter (Above 1.0 to $1.5 \mu \mathrm{m}$ )

Type H: Chromosome with submedian centromere.

Type I: Chromosome with median centromere.

Type J: Chromosome with subterminal centromere.

Shortest $(1.0 \mu \mathrm{m}$ and below $1.0 \mu \mathrm{m})$

Type $K$ : Chromosome with submedian centromere.

Type L: Chromosome with median centromere.

Type M: Chromosome with subterminal centromere.

The secondary constricted chromosomes are present in only 6 species and in these, the number of such chromosomes has been found to vary from species to species, The karyomorphological features of the various species studied are summarised in the following table. (Table 2).

Meiotic studies have been made (Figs. 33 to 87 and 7 to 13) in Laportea terminalis, Pilea microphylla, $P$. involucrata, Pellionia repens, Pouzolzia cymosa, $P$. wightii, P. bennettiana and $P$. zeylanica. In these species, the meiotic chromosome numbers are in correlation with the respective mitotic chromosome numbers.

\section{Discussion}

First record of chromosome number has been made in 14 species of Urticaceae with present investigation (Table 1). Deviant report as against the previous record of chromosome number has been made in Elatostemma acuminatum. In Elatostemma sessilis and Pilea cadierei, the present reports of chromosome numbers are in correlation with the earlier reports (Table 1).

There is a range of chromosome numbers from $2 n=18$ to $2 n=50,2 n=20,2 n=30$ and $2 n=50$ have been observed in 5 species and $2 n=24$ and $2 n=48$ have been observed in another 5 species, respectively. Therefore, it is assumed that $\mathrm{n}=10$ may be the primary basic chromosome number of this family and $n=12$ the derived basic chromosome number. The higher numbers observed in the rest of the species should have been evolved by means of euploidy and aneuploidy. The graphic representation drawn from the frequency distribution of diploid chromosome numbers of the various species of Urticaceae studied (Fig. 32) shows a trimodel curve or three peaks of raising. This shows 3 lines of evolution, one with species having $2 n=$ 20 chromosomes, the second with species having $2 n=24$ chromosomes and the third with species possessing $2 \mathrm{n}=32$ chromosomes.

There is considerable variation in the karyotypes of various species studied. Each and every species has distinct karyotype. Even the species of a particular genus namely Elatostemma, Pilea and Pouzolzia have distinct karyotypes (Table 2). Therefore, it is concluded that karyotype alterations of chromosomes play important role in speciation, along with euploidy and aneuploidy already discussed. There is considerable variations of karyotype sym- 
metry or asymmetry among the species studied in the same way as there is variation of somatic chromosome numbers.

In general, the chromosomes are smaller in size in most of the taxa studied. In Elatostemma acuminatum there are $2 \mathrm{n}=20$ chromosomes and the size ranges from 1.6 to $3.0 \mu \mathrm{m}$. In Laportea terminalis the same $2 \mathrm{n}=20$ chromosomes are present but they are smaller ranging from 0.8 to $1.6 \mu \mathrm{m}$. In both Pilea microphylla and $P$. cadierei, there are $2 \mathrm{n}=50$ and 48 chromosomes respectively and the chromosomes are smaller, ranging from 0.8 to $1.6 \mu \mathrm{m}$ and 0.8 to $1.8 \mu \mathrm{m}$ respectively. But, in Elatostemma sessilis, there are $2 \mathrm{n}=32$ chromosomes, but they are larger ranging from 1.8 to $2.4 \mu \mathrm{m}$. Therefore, there is no correlation between the size and number of chromosomes of the species studied.

In Pilea involucrata, Pellionia repens, Pouzolzia wightii, P. bennettiana and P. zeylanica, precocious movements of chromosomes during I metaphase have been observed. This is due to earlier separation of univalents in some of the bivalents and earlier movements of chromosomes to a particular pole whereas the univalents in the other bivalents do not separate so earlier. Sometimes the entire bivalent will move to a particular pole showing precocious movements.

Anaphasic laggards have been found in Pouzolzia cymosa and anaphasic laggards and bridges in $P$. bennettiana and $P$. zeylanica. The presence of these meiotic abnormalities and precocious movements of chromosomes shows the close relationships of the species of Pouzolzia and these abnormalities may be due to inversion heterozygosity. The frequency of bridge formation in any species depends on three factors namely chiasma frequency, number of inversions and size of inversions. Out of 17 species of Urticaceae studied, laggards and bridges have been noted in 3 species only. Therefore, these abnormalities do not play important role in specieation.

The separation of bivalents, and multivalents into univalents during metaphase and anaphase is abnormal. Therefore, unequal number of chromosomes will reach the respective poles during first division of PMCs and the second division is also unequal, leading to the formation of 4 unequal gametes. The formation of multivalents, quadrivalents and trivalents may be attributed to polyploidy or structural alteration of chromosomes. The species of Urticaceae studied are aneuploids and euploids and therefore, it is due to this polyploidy that there are occurrences of multivalents, quadrivalents and trivalents.

\section{Summary}

Cytotaxonomical studies have been made in 17 species coming under 7 genera of South Indian Urticaceae. First record of chromosome number has been made in 1. Laportea terminalis, 2. Elatostemma lineolatum, 3. E. surculosum, 4. Pilea trinervia, 5. P. microphylla, 6. $P$. involucrata, 7. Pellionia repens, 8. Pouzolzia auriculata, 9. P. cymosa, 10. P. wightil, 11. P. bennettiana, 12. P. zeylanica, 13. Drougetia diffusa, and 14. Villebrunea integrifolia.

The somatic chromosome number ranges from 18 to 50 among the species studied. $\mathbf{n}=10$ may be the primary basic chromosome number and $n=12$ derived basic chromosome number. All the other numbers might have been produced by means of euploidy and aneuploidy. The karyotype analyses show that each and every species has a distinct karyotype. Therefore, karyotype alteration of chromosomes play important role in speciation along with aneuploidy and euploidy already discussed.

\section{Acknowledgement}

The authors express their heartfelt thanks to Dr. R. Ganesan, Professor and Head of the 
Dept. of Botany, Annamalai University for his encouragement and facilities provided throughout the course of this investigation.

\section{References}

Fedorov, A. N. A. 1974. Chromosome Number of Flowering Plants. Otto Koelts Science publishers, n-624 Koenigstein/West Germany.

Gamble J. S. 1957. Flora of the Presidency of Madras. B. S. I. Publication-Calcutta-Vol. III.

Marimuthu K. M. and Subramaniam, M. K. 1960. A haematoxylin squash method for the root tips of Dolichos lablab L. Curr. Sci. 29: 482-483.

Strasburger, E. 1910. Sexuelle und apogame Fortpflanzung bei Urticaceaue. Jahrb. Wissensch. Bot. 47(3): 245-283.

Krause, O. 1931. Zytologische Studien bei den Urticales unter besonderer Berücksichtgung für Gattung Dorstenia. Planta 13(1): 29-84.

Hamel, J. L. 1939. Note sur la mitose somatique d'une urticaceae nouvella cultivee dans les serres du Musium Bull. Mus. Natl. His. Nat; 11(2): 271-272.

Lecoq, C. 1963. Contribution a l'etude cytotaxinomique des moracees et des urticacees. Rev. Gen. Bot. 70(830): 385-426.

Lawrence, G. H. M. 1957. Taxonomy of Vascular Plants. The Macmillan Co. New York. 